\title{
Effect of High-Hydrostatic Pressure and Temperature on Rheological Characteristics of Glycomacropeptide
}

\author{
J. Ahmed ${ }^{1}$ and H. S. Ramaswamy \\ Department of Food Science and Agricultural Chemistry \\ Macdonald Campus of McGill University \\ Ste. Anne de Bellevue, PQ, Canada H9X 3V9
}

\section{ABSTRACT}

The influences of high pressure and temperature on the rheological characteristics of glycomacropeptide (GMP) were studied using a controlled rate rheometer. GMP dispersions at a concentration of $12.5 \%(\mathrm{w} / \mathrm{w})$ were subjected to high pressure from 100 to $400 \mathrm{MPa}$ for 30 min and temperature from 20 to $80^{\circ} \mathrm{C}$ for $15 \mathrm{~min}$ followed by rheological measurements at a shear rate ranged between 0 and $200 \mathrm{~s}^{-1}$. Shear stress-shear rate data of both pressure and heat induced GMP samples fitted Herschel-Bulkley model well with yield stress. It exhibited shear-thinning behavior with flow behavior index ranged between 0.882 and 0.996 . Consistency coefficient and apparent viscosity increased with pressure up to $300 \mathrm{MPa}$ while those parameters decreased at $400 \mathrm{MPa}$. The rheology of GMP was influenced by temperature. The consistency coefficient and apparent viscosity at $100 \mathrm{~s}^{-1}$ obeyed the Arrhenius relationship with activation energies ranged between 8.17 to $12.38 \mathrm{~kJ} /$ mol. Lower activation energy signified lesser molecular aggregation or unfolding of protein molecules during thermal treatment of GMP.

(Key words: consistency coefficient, flow behavior index, glycomacropeptide, high pressure and temperature)

Abbreviation key: GMP = glycomacropeptides, HPP = high hydrostatic pressure processing, $\mathbf{K}=$ consistency coefficient, $\mathbf{n}=$ flow behavior index.

\section{INTRODUCTION}

High-hydrostatic pressure processing (HHP) has been reported a promising area for various foods applications and will now deliver the ultimate convenience for consumers (Meyer et al., 2000; Sizer et al., 2002).

Received August 14, 2002.

Accepted October 7, 2002.

Corresponding author: Jasim Ahmed; e-mail: jahmed@uaeu.ac.ae.

${ }^{1}$ Present address: Department of Food Science, College of Food System, UAE University, PO Box 17555; Al Ain; United Arab Emirates.
Various researchers have reported the applications of HHP in different areas of food processing like inactivation of microorganisms and enzymes (Alderton et al., 1976; Oxen and Knorr, 1993; Arroyo et al., 1997; Berlin et al., 1999; Mussa et al., 1999; Denys et al., 2000), denaturation and functionality of proteins (Hayakawa et al., 1992; Knorr, 1995; Lee et al., 1999) structure change of food materials (Van Camp and Huyghebaert, 1995; Hosseini-nia et al., 2002). The major researches on HPP have been focused on food protein and its functional properties, modification and gel rigidity and water holding capacity (Johnston et al., 1993). Such studies have involved in milk proteins, polysaccharides and combinations of them.

Knowledge of the rheological properties of food products is essential for the product development, quality control, sensory evaluation and design and evaluation of the process equipment. Rheological measurements have also been considered as an analytical tool to provide fundamental insights on the structural organization of food and play an important role in heat transfer to fluid foods. The flow behavior of a fluid can range from Newtonian to time dependent non-Newtonian in nature depending on its origin, composition and structure behavior and previous history (Rao, 1986). The role of protein structure on rheology of emulsion and gel is a complex one and fundamental rheological tests provide critical information on time dependent viscoelastic behavior and the molecular mechanisms surrounding the changes in structure when a protein undergoes gelation (Phillips et al. 1994). Food proteins and milk products are compositionally and structurally complex materials and can exhibit a wide range of rheological properties at different conditions. The rheological properties of these products are strongly influenced by temperature, concentration and physical state of dispersion (van Vliet and Walstra, 1980). Therefore, it is interesting to study the rheological properties of proteinous and dairy products as function of temperature and high pressure.

Glycomacropeptide (GMP) is a highly biologically active whey protein with superior purity and is considered by some to be a designer protein. It is one of the im- 
portant minor proteins present in whey along with lactoperoxidase, lactoferrin and protease peptones (Belem et al., 1999). GMP present in cheese whey is a C-terminal glycopeptide released from $\kappa$-casein by the action of chymosin at Phe-105 and Met-106 (Eigel et al., 1984). It is a unique peptide composed of a chain of 64 amino acids with a molecular weight of 6700 daltons. Researchers have identified five different heterogeneous sugar chains related to GMP derived from mature bovine milk. The most prominent of these is $\mathrm{N}$-acetylneuraminic acid, commonly known as sialic acid. GMP has a purity level of over $90 \%$ and is also highly glycosylated with 7 to $8 \%$ sialic acid. The peptide has no aromatic amino acids (phenyl alanine, tyrosine, tryptophan) while rich in branched-chain amino acids (leucine, isoleucine, and valine) (Eigel et al., 1984).

The GMP is available in a light colored, mild tasting, free flowing powder ideal for usage in both functional foods and dietary supplements. It has several health benefits like dental caries and plaque reduction; immuno-modulatory effects and affords a passive defense mechanism to newborns (Broody, 2000). GMP is useful in the treatment of phenylketonuria and considered as an ideal ingredient in nutritional formulations for people suffering from hepatic diseases (Eryck et al., 2002). Keeping in view of all these health benefits, presently the health food manufacturers have extensively used GMP as an ingredient for their products however; no report is available on the rheological characteristics of GMP.

Therefore the objective of this work was to provide a study of rheological changes of GMP upon exposure to high pressures from 100 to $400 \mathrm{MPa}$ for $30 \mathrm{~min}$ and temperature from 20 to $80^{\circ} \mathrm{C}$ for $15 \mathrm{~min}$.

\section{MATERIALS AND METHODS}

\section{Materials}

The GMP samples were provided by Davisco Food International (MN, USA). As per manufacturer's analysis, glycomacropeptides contains $6 \pm 0.2 \%$ moisture, $12.2 \pm 0.2 \%$ total nitrogen, $85 \pm 1.5 \%$ GMP $(\mathrm{N} \times 6.94)$, fat $0.6 \pm 0.2$, ash $6.3 \pm 0.2 \%$ and lactose $<1 \%$. The purity of the GMP has been reported as $97 \pm 1$ and contains $8 \pm 0.4 \%$ sialic acid.

\section{Sample Preparation}

Samples of $12.5 \%$ GMP solutions were prepared (w/ w) by addition of required amount GMP and deionized water (conductance: $18 \Omega$, Milli-Q, Millipore, Bedford, USA) under stirring and kept for $6 \mathrm{~h}$ at refrigerated temperature $\left(4\right.$ to $\left.6^{\circ} \mathrm{C}\right)$ for hydration. The concentration was selected to avoid gel formation. Each sample was prepared in duplicate. The $\mathrm{pH}$ of the GMP solution was 7.01 .

\section{High Hydrostatic Pressure Treatment}

An isostatic high-pressure machine unit (Model\# CIP 42260, ABB Autoclave System, Columbus, OH, USA) with chamber dimension of $0.55 \mathrm{~m}$ height and $0.1 \mathrm{~m}$ diameter was used to generate high-pressure levels. Distilled water containing $2 \%$ water soluble oil (Part No. 5019, Autoclave Engineers, Columbus, OH, USA) was used as the pressure medium for pressurization. A smooth pressure rise of $2.4 \mathrm{MPa} \mathrm{s}^{-1}$ after an initial delay of $15 \mathrm{~s}$ occurred during pressurization. The comeup time for pressurization ranged from $33 \mathrm{~s}$ to $2.8 \mathrm{~min}$ depending upon the pressure level, and the depressurization time was $\sim 10 \mathrm{~s}$. The temperature of the sample was controlled by circulating cold water. The medium temperature was recorded by a thermocouple (K-type) and a data logger during the experimentation.

The test pouches were submerged in water for the pressurization. The pressure applied to the test sample ranged between 100 and $400 \mathrm{MPa}$ with an increase of $100 \mathrm{MPa}$ for a residence time of $30 \mathrm{~min}$ at $20\left( \pm 1^{\circ} \mathrm{C}\right)$. Pressure treatment time mentioned in the study did not consider the pressure build up or releasing time. Duplicate samples were used for each pressure treatment. The pressure treated pouches were immediately transferred to refrigerator $\left(4\right.$ to $6^{\circ} \mathrm{C}$ ) and subsequently studied the rheology.

\section{Rheological Measurement}

Rheological measurements were carried out in a controlled stress rheometer (AR 2000, TA Instruments, New Castle, DE, USA) with attached computer software (Rheology Advantage Data Analysis Program, TA). A double concentric cylinder (stator outer radius $20 \mathrm{~mm}$; rotor inner radius $20.38 \mathrm{~mm}$; rotor outer radius $21.96 \mathrm{~mm}$; immersed height $59.5 \mathrm{~mm}$ and gap $500 \mathrm{mi}-$ crons) geometry was used for rheological measurement. The AR 2000 Concentric Cylinder System is based on efficient peltier temperature control and temperature was efficiently monitored during the experiments.

For each test, the measured volume of sample (approximately $6.48 \mathrm{ml}$ ) was transferred to sample compartments. The instrument was programmed for set temperature and equilibration for 10 min followed by two-cycle shear changes from 0 to $200 \mathrm{~s}^{-1}$ in $5 \mathrm{~min}$ and by back to $0 \mathrm{~s}^{-1}$ in next $5 \mathrm{~min}$. All the rheological parameters were obtained from the software (Rheology Advantage, TA version 2.3). In order to perform a quantitative comparison of temperature and pressure treated samples various rheological flow models based 
NEED RUNNING HEAD

Table 1. Fitting of various flow models for GMP at $100 \mathrm{MPa}$ for $30 \mathrm{~min}$.

\begin{tabular}{llllll}
\hline No. & Model & $\begin{array}{l}\text { Yield } \\
(\mathrm{Pa})\end{array}$ & $\begin{array}{l}\text { Consistency } \\
\text { coefficient }\left(\mathrm{Pa} \cdot \mathrm{s}^{\mathrm{n}}\right)\end{array}$ & $\begin{array}{l}\text { Flow behavior } \\
\text { index }(-)\end{array}$ & $\begin{array}{l}\text { Standard } \\
\text { error }\end{array}$ \\
\hline 1 & Newtonian model & - & $0.0025^{1}$ & - & 22.17 \\
2 & Power law model & - & 0.0042 & 0.903 & 8.21 \\
3 & Casson model & 0.0004 & $8.6 \mathrm{E}-6$ & - & 59.16 \\
4 & Bingham model & 0.0208 & 0.0024 & - & 8.81 \\
5 & Herschel Bulkley model & 0.0055 & 0.0031 & 0.927 & 7.11 \\
\hline
\end{tabular}

${ }^{1}$ Apparent viscosity, $\mathrm{Pa} \cdot \mathrm{s}$.

on shear stress-shear rate were tested (Newton, Bingham, Casson, power law, Herschel Bulkley) and the best fit model was selected on the basis of standard error, which is defined as:

$$
\left[\Sigma\left(\mathrm{X}_{\mathrm{m}}-\mathrm{X}_{\mathrm{c}}\right)^{2} /(\mathrm{n}-2)\right]^{0.5} / \text { Range } \times 1000
$$

Where $\mathrm{X}_{\mathrm{m}}$ is the measured value; $\mathrm{X}_{\mathrm{c}}$ is the calculated value; $\mathrm{n}$ is the number of data points and range is the maximum value of $\mathrm{X}_{\mathrm{m}}$ - the minimum value.

\section{Statistical Analysis}

Statistical analysis was carried out as per method described by Gacula and Singh (1994). Trends were considered significant while means of compared sets differed at $P<0.05$ (Student's $t$-test).

\section{RESULTS AND DISCUSSION}

\section{Flow Models}

Shear stress-shear rate data of the heat and pressurized GMP samples were tested for various rheological models (Newtonian, Casson, Bingham, power and Herschel-Bulkley), and it was found that Herschel Bulkley model was fitted adequately (Table 1). The Herschel Bulkley model is represented as:

$$
\tau=\tau_{0}+\mathbf{K}(\gamma)^{\mathrm{n}}
$$

Where $\tau$ is the shear stress (Pa), $\tau_{0}$ is the yield stress, $\gamma$ is the shear rate $\left(\mathrm{s}^{-1}\right), \mathrm{K}$ is the consistency coefficient $\left(\mathrm{Pa} \cdot \mathrm{s}^{\mathrm{n}}\right)$, and $\mathrm{n}$ is the flow behavior index (dimensionless). The GMP samples exhibited definite yield stress. No significant $(P<0.05)$ variations in the up and downward curves of GMP samples were observed during heat or pressure treatment and therefore, the fluid were nonthixotropic. The average rheological parameter values of up and down curves are reported in the present paper.

\section{Effect of High Pressure on Rheological Characteristics of GMP}

The rheogram for pressure treated samples of GMP are presented in Figure 1. The control sample was considered at atmospheric pressure and $20^{\circ} \mathrm{C}$. Shear stress increased with pressure at a constant shear rate up to $300 \mathrm{MPa}$ and decreased at $400 \mathrm{MPa}$ (Figure 1). The rheological parameters of pressure treated GMP samples are reported in Table 2. The yield stress increased with the increase of the pressure from 200 to $300 \mathrm{MPa}$ and followed by decreasing at $400 \mathrm{MPa}$. The magnitude of the consistency coefficient (K) of control sample was found to be $0.0027 \mathrm{~Pa} \cdot \mathrm{s}^{\mathrm{n}}$ that consistently increased to $0.0033 \mathrm{~Pa} \cdot \mathrm{s}^{\mathrm{n}}$ during pressurization except at $400 \mathrm{MPa}$ (Table 2). The flow behavior index (n) ranged between 0.927 and 0.966 . The observed $\mathrm{n}$ values indicated that the GMP solution exhibited pseudoplasticity while no systematic trend was noticed for the same. The trend of apparent viscosity was similar to consistency coefficient, which increased linearly with pressure level. The magnitudes of consistency coefficient, apparent viscosity and flow behavior index decreased at $400 \mathrm{MPa}$. However, the changes in the magnitude of rheological parameters during pressurization were insignificant $(P>$ 0.05). The decrease in rheological parameters at 400 $\mathrm{MPa}$ might be attributed by slight deformation of $\kappa$-CN bonds and change of orientation. The energy generation

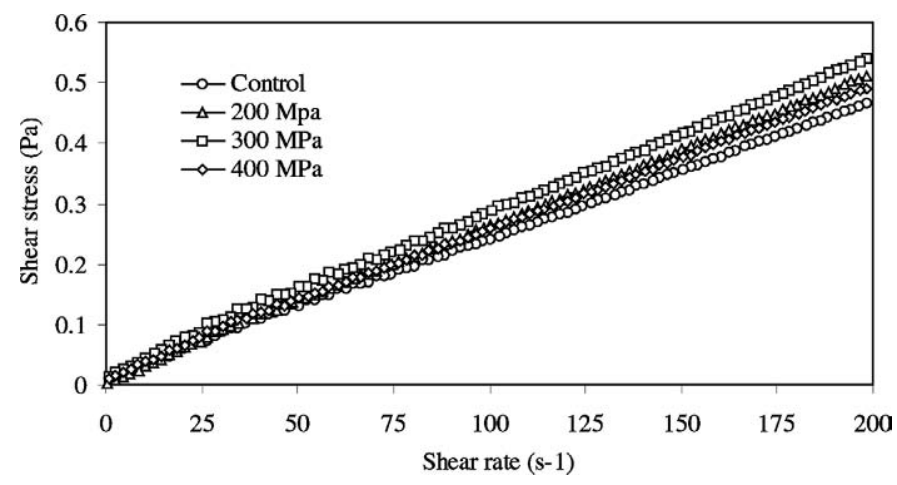

Figure 1. Effect of pressure on rheology of glycomacropeptide. 
Table 2. Effect of pressure on rheological parameters of GMP.

\begin{tabular}{lllll}
\hline $\begin{array}{l}\text { Pressure } \\
(\mathrm{MPa})\end{array}$ & $\begin{array}{l}\text { Yield } \\
\text { stress }(\mathrm{Pa})\end{array}$ & $\begin{array}{l}\text { Consistency } \\
\text { coefficient }(\mathrm{K}), \\
\mathrm{Pa} \cdot \mathrm{s}^{\mathrm{n}}\end{array}$ & $\begin{array}{l}\text { Flow } \\
\text { behavior } \\
\text { index } \\
(\mathrm{n})\end{array}$ & $\begin{array}{l}\text { Standard } \\
\text { error }\end{array}$ \\
\hline 0 & 0.0109 & 0.0027 & 0.966 & 6.043 \\
100 & 0.0055 & 0.0031 & 0.927 & 7.105 \\
200 & 0.0018 & 0.0032 & 0.955 & 5.919 \\
300 & 0.0132 & 0.0033 & 0.961 & 7.668 \\
400 & 0.0084 & 0.0031 & 0.940 & 5.851 \\
\hline
\end{tabular}

from high-pressure is only $9.6 \mathrm{~kJ} / \mathrm{g}$ mol per $10^{4} \mathrm{MPa}$ and it could not completely disrupt those bonds (Hayakawa et al. 1992). It supports the lower texture degradation during high pressure. The coagulation of protein observed at pressure level of $400 \mathrm{MPa}$, which was reflected through decrease in magnitudes of shear stress, consistency coefficient and apparent viscosity. Lopez et al. (1996) reported that denaturation of protein was expected at above $300 \mathrm{MPa}$ while the pressure level above $200 \mathrm{MPa}$ was sufficient for $\beta$-lactoglobulin. In the present study, the protein denaturation initiated at $300 \mathrm{MPa}$.

\section{Effect of Temperature on Rheological Characteristics of GMP}

Temperature has an important role on rheological characteristics of any food products. The effect of temperature on rheological characteristics of GMP is shown in Figure 2. It is evident from the Figure that an increase in temperature reduced the shear stress at a constant shear rate. The rheological parameters of GMP during heat treatment are reported in Table 3. The yield stress, consistency coefficient and flow behavior index decreased significantly $(P<0.05)$ during thermal treatment. However, the slight increase in magnitude of $\mathrm{K}$ at $80^{\circ} \mathrm{C}$ indicated phase transformation of GMP solution to gel. A unique trend was noticed for

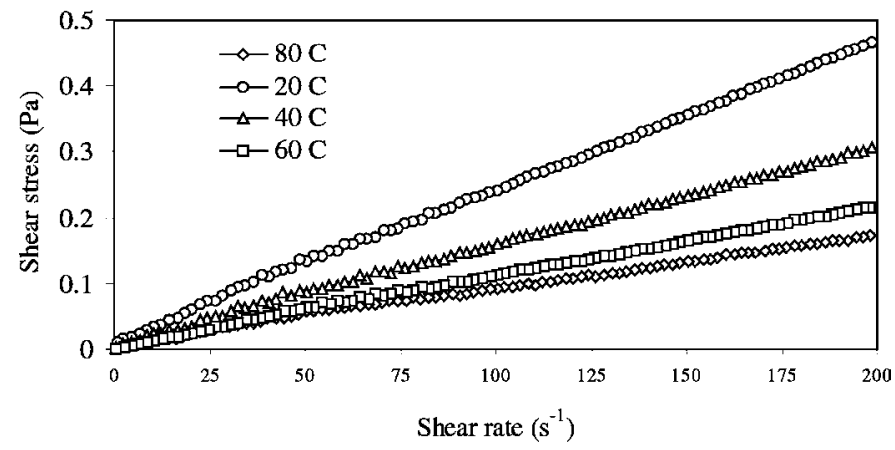

Figure 2. Effect of temperature on rheology of glycomacropeptides. flow behavior index. The magnitude of $\mathrm{n}$ decreased from 0.966 to 0.882 during heat treatment from 20 to $80^{\circ} \mathrm{C}$. Van Camp and Huyghebaert (1995) advocated that the heat induced protein structure (gel) was strong with significant loss of water and dry in appearance. They also observed higher levels of cross-links in heat-induced gels through electron microscopy. These could be the possible reasons for the decrease in the values of $n$ and $\mathrm{K}$ at higher temperatures.

Temperature dependency of consistency coefficient and apparent viscosity at constant shear rate $\left(100 \mathrm{~s}^{-1}\right)$ is expressed by Arrhenius relationship (Equations 3 and 4):

$$
\begin{gathered}
\mathrm{K}=\mathrm{A}_{\mathrm{k}} \exp \left(\mathrm{E}_{\mathrm{K}} / \mathrm{RT}\right) \\
\eta=\mathrm{A}_{\eta} \exp \left(\mathrm{E}_{\eta} / \mathrm{RT}\right)
\end{gathered}
$$

Where $\mathrm{K}$ is the consistency coefficient, $\eta$ is the apparent viscosity at shear rate of $100 \mathrm{~s}^{-1}, \mathrm{~A}_{\mathrm{k}}, \mathrm{A}_{\eta}$ are the preexponential constants; $\mathrm{E}$ is the activation energy; $\mathrm{R}$ is the universal gas constant and $\mathrm{T}$ is absolute temperature.

Figure 3 shows the temperature dependence of consistency coefficient and apparent viscosity of GMP. The coefficients of Equations 3 and 4 were computed using the least square technique. Magnitudes of the energy of activation relating to consistency coefficient and apparent viscosity ranged between 8.17 and $12.38 \mathrm{~kJ} / \mathrm{g}$ mol respectively while the corresponding magnitudes of constants $\left(\mathrm{A}_{\mathrm{k}}\right.$ and $\left.\mathrm{A}_{\eta}\right)$ were $9.57 \times 10^{-5} \mathrm{~Pa}$ and 1.52 $\times 10^{-5} \mathrm{~Pa} \cdot \mathrm{s}$ respectively. The $\mathrm{R}^{2}$ for both cases were greater than 0.976 while standard error were less than 0.052 . These values indicated that both $\mathrm{K}$ and $\eta$ follow Arrhenius model. There was significant difference in activation energies. This difference is due to a single value obtained from the instrument $\left(\eta\right.$ at $100 \mathrm{~s}^{-1}$ ) and another from the entire experimental data ( $\mathrm{K}$ value). The obtained activation energy for GMP was too low compared to other whey protein components. The $\mathrm{E}$ values were found to be very high for $\alpha$-lactoalbumin, $\beta$ lactoglobulin and lactoferrin (136-280 kJ/g mol) where cleavage and denaturation of proteins have been re- 
Table 3. Effect of temperature on rheological parameters of GMP at atmospheric pressure.

\begin{tabular}{llllc}
\hline $\begin{array}{l}\text { Temperature } \\
\left({ }^{\circ} \mathrm{C}\right)\end{array}$ & $\begin{array}{l}\text { Yield } \\
\text { stress }(\mathrm{Pa})\end{array}$ & $\begin{array}{l}\text { Consistency } \\
\text { coefficient }(\mathrm{K}), \\
\mathrm{Pa} \cdot \mathrm{s}^{\mathrm{n}}\end{array}$ & $\begin{array}{l}\text { Flow } \\
\text { behavior } \\
\text { index }(\mathrm{n})\end{array}$ & $\begin{array}{l}\text { Standard } \\
\text { error }\end{array}$ \\
\hline 20 & 0.0109 & 0.0027 & 0.966 & 6.043 \\
40 & 0.0047 & 0.0020 & 0.950 & 8.041 \\
60 & 0.0018 & 0.0015 & 0.933 & 8.016 \\
80 & 0.0012 & 0.0016 & 0.882 & 12.27 \\
\hline
\end{tabular}

ported at higher temperature (Sanchez et al. 1992). The predicted $\mathrm{E}$ value of GMP indicated that a minimum number of bonds were unfolded and denatuartion of protein had not been completely occurred at a temperature range of $20-80^{\circ} \mathrm{C}$.

\section{CONCLUSIONS}

The rheological characteristics of GMP samples studied without additional heat supply after high pressure treatment at 100 to $400 \mathrm{MPa}$ for $30 \mathrm{~min}$ at $20^{\circ} \mathrm{C}$. The rheological characteristics were also investigated for temperature range between 20 and $80^{\circ} \mathrm{C}$ for $15 \mathrm{~min}$ at atmospheric pressure. Both pressure and heat treated samples followed Herschel-Bulkley model and exhibited shear-thinning behavior. Samples pressurized at $400 \mathrm{MPa}$ and thermally treated at $80^{\circ} \mathrm{C}$ behaved differently from those corresponding pressure and temperature treated samples. The observations indicated that it could be due to cleavage of $\kappa$-CN bonds during high pressure $(400 \mathrm{MPa})$ and high temperature $\left(80^{\circ} \mathrm{C}\right)$. However, heat induced protein structure was strong with significant loss of water while high pressure formed a weak network without much alteration on $\kappa$-CN bonds. In order to obtain specific gel characteristics and their relative contribution to the rheological characteristics, it might be of interest to study the infrared and electron microscopy of GMP during pressure and heat treatment.

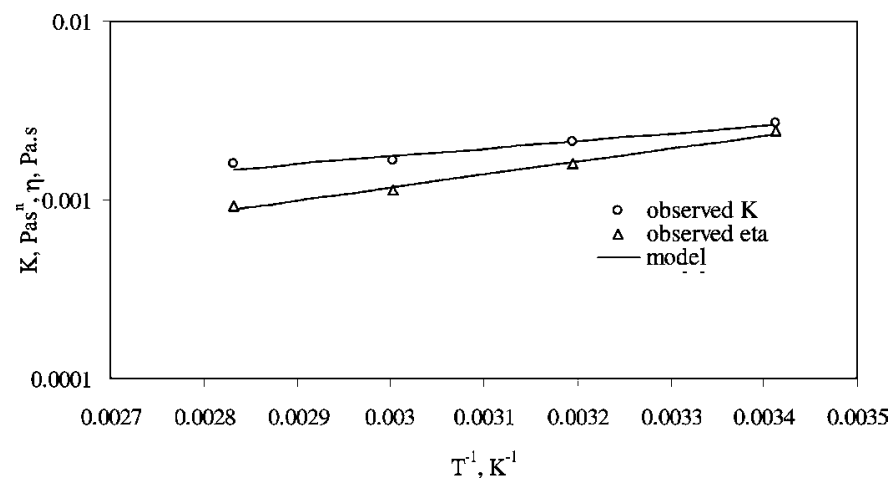

Figure 3. Arrhenius plot depicting the temperature dependence of consistency coefficient and apparent viscosity of GMP.

\section{ACKNOWLEDGMENTS}

The authors wish to acknowledge Dr. M. Ngadi at Department of BioSystem \& Agricultural Engineering for his permission to work on rheometer and Dr. A.A. Ismail at Department of Food Science \& Agricultural Chemistry, McGill University, Canada for his interest on the work and valuable suggestions.

\section{REFERENCES}

Alderton, G., K. A. Ito, and J. K Chen. 1976. Chemical manipulation of the heat resistance of Clostridium botulinum spores. Appl. Environ. Microbiol. 31:492-498.

Arroyo, G., P. D. Sanz, and G. Prestamo. 1997. Effect of high pressure on the reduction of microbial populations in vegetables. J. Appl. Microbiol. 82:735-742.

Belem, M. A. F., B. F. Gibbs, and B. H. Lee. 1999. Proposing sequences for peptides derived from whey fermentation with potential bioactive sites. J. Dairy Sci. 82:86-93.

Eryck, R., S. Hernandez, D. L. Berlin, D. S. Herson, D. T. Hicks, and D. G. Hoover. 1999. Response of pathogenic vibrio species to high hydrostatic pressure. Appl Environ Microbiol. 65: 2776-2780.

Broody, E. P. 2000. Biological activities of bovine glycomacropeptide. Br. J. Nutr. 84:Supp. 1.S39-S46.

Denys, S., L. R. Ludikhuyze, A. M. Van Loey, and M. E. Hendrickx. 2000. Modeling conductive heat transfers and process uniformity during batch high-pressure processing of foods. Biotechnol. Prog. 16:92-101.

Eigel, W. N., J. E. Butler, C. A. Ernstrom, H. M. Farell Jr., V. R. Harwalker, R. Jenness, R. Mc.L. Whitney. 1984. Nomenclature of proteins in cow's milk. Fifth revision. J. Dairy Sci. 67: 1599-1631.

Gacula, M. C., and J. Singh. 1984. Statistical Methods in Food and Consumer Research. Academic Press, London.

Hayakawa, I., J. Kajihara, K. Morikawa, M. Oda, and Y. Fujio. 1992 Denaturation of bovine serum albumin and ovalbumin by high pressure, heat and chemicals. J. Food Sci. 57:288-292.

Hayashi, R. 1992. Utilization of pressure in addition to temperature in food science and technology, In: High Pressure and Biotechnology, C. Balny, R. Hayashi, K. Colloque. INSERM/John Libbey Eurotext Ltd.

Hosseini-nia, T., A. A. Ismail, and S. Kubow. 2002. Effect of high hydrostatic pressure on the secondary structures of BSA and Apoand Holo- $\alpha$-Lactalbumin employing fourier transform infrared spectroscopy. J. Food Sci. 67: 1341-1347.

Johnston, D. E., B. A. Austin, and R. J. Murphy. 1993. Properties of acid-set gels prepared from high pressure treated skim milk. Milchwissenchaft. 48:206-209.

Knorr, D. 1995. High pressure effects on plant derived foods. Ch. 9. In: High Pressure Processing of Foods, D. A. Ledward, D. E. Johnston, R. G. Earnshaw and A. P. M. Hasting (Ed.) p. 123136. Nottingham University Press, Nottingham.

Lee, D., V. Heinz, and D. Knorr. 1999. Evaluation of processing criteria for the high pressure treatment of liquid whole egg: rheological study. Lemnsm-wiss-u-Technol. 32:299-304. 
Lopez Fardino, R., A. V. Carrascosa and A. Olano. 1996. The effects of high pressure on whey protein denaturation and cheese making properties of raw milk. J. Dairy Sci. 79:929-936.

Meyer, R. S., K. L. Cooper, D. Knorr, and H. L. M. Lelieveld. 2000. High pressure sterilization of foods. Food Technol. 54(11):67$68,70,72$.

Musa, D., H. S. Ramaswamy, and J. P. Smith. 1999. High pressure destruction kinetics of Listeria monocytogens on pork. J. Food Protect. 62:40-45.

Nakano, T., and L. Ozimek. 2002. Isolation and analysis of k-casein glycomacropeptide from goat sweet whey. J. Agric. Food Chem. 50:2034-2038.

Oxen, P., and D. Knorr. 1993. Baroprotective effects of high solute concentrations against inactivation of Rhodotorula rubra. Lebensm-wiss-u-Technol. 26:220-223.
Phillip, L. G., D. M. Whitehead, and J. Kinsella. 1994. Protein gelation. Pages 179-204 in Structure-function properties of food proteins. Academic Press. Inc. California.

Rao, M. A. 1986. Rheological properties of fluid foods. Pages 1-47 in Rao, M. A. and Rizvi, S. S. H. (Eds.) 1986. Engineering properties of foods. Marcel Dekker, New York.

Sanchez, L., J. M. Peiro, H. Castillo, M. D. Perez, J. M. Ena, and M. Kalvo. 1992. Kinetic parameters for denaturatation of bovine milk lactoferrin. J Food Sci. 57:873-879.

Sizer, C. E., V. M. Balasubramanium, and E. Ting. 2002. Validating high-pressure process for low acid foods. Food Technol. $56(2): 36-42$

Van Camp, J., and A. Huyghebaert. 1995. A comparative rheological study of heat and high pressure induced whey protein gels. Food Chemistry. 54:357-364.

van Vliet, T., and P. Walstra. 1980. Relationship between viscosity and fat content of milk and cream. J. Tex. Studies. 11:65-70. 